(3)

Volume 21, 2018

\title{
LADIES FIRST: THE INFLUENCE OF MOBILE DATING APPLICATIONS ON THE PSYCHOLOGICAL EMPOWERMENT OF FEMALE USERS
}

Maureen Tanner*

Pabie Q Tabo

* Corresponding author
University of Cape Town, Cape Town, mc.tanner@uct.ac.za South Africa

University of Cape Town, Cape Town, tbxpab001@myuct.ac.za South Africa

\section{ABSTRACT}

Aim/Purpose

This study was undertaken to shed light on how the use of a heteronormative mobile dating application creates an environment to promote psychological empowerment among female users within the online dating scene. The study focused on a mobile dating application which specifically challenges traditional gender roles, namely Bumble.

Background Mobile dating applications have become an increasingly popular medium for people to meet potential partners. However, users' pre-existing social norms and biases inform how they communicate on these platforms, and stereotyped judgment about women perpetuates ideologies which continue to oppress them within the cyber world. Despite this, very little research has investigated the experiences of female users of mobile dating applications.

Methodology The study was qualitative in nature, and 10 semi-structured interviews of female Bumble users were conducted. The data were analyzed using thematic analysis.

Contribution The study contributes to knowledge by highlighting how key features of mobile dating applications influence various aspects of psychological empowerment as articulated in the findings.

Findings The findings show that the Bumble application supports Intrapersonal variables of Psychological Empowerment of female users relative to Domain Specific Perceived Control and Self-Efficacy, Motivation to Control and Perceived Competence. However, Domain Specific Perceived Control can also be negatively impacted due to self-doubt when female users receive little to no matches.

Accepting Editor Peter Rittgen | Received: August 13, 2018 | Revised: October 17, October 20, 2018 | Accepted: October 25, 2018.

Cite as: Tanner, M., \& Tabo, P. Q. (2018). Ladies first: The influence of mobile dating applications on the psychological empowerment of female users. Informing Science: the International Journal of an Emerging Transdiscipline, 21, 289-317. https://doi.org/10.28945/4137

CC BY-NC 4.0) This article is licensed to you under a Creative Commons Attribution-NonCommercial 4.0 International License. When you copy and redistribute this paper in full or in part, you need to provide proper attribution to it to ensure that others can later locate this work (and to ensure that others do not accuse you of plagiarism). You may (and we encourage you to) adapt, remix, transform, and build upon the material for any non-commercial purposes. This license does not permit you to use this material for commercial purposes. 
Interactional variables of psychological empowerment are also supported, as Bumble allows female users to be critically aware of the need to screen potential partners, understand relevant causal agents, develop skills relative to initiating conversations and mobilize resources. However, Bumble is not effective in supporting behavioral variables of psychological empowerment because of limitations in the tool's functionality and the behavior of the people interacting on the platform.

Recommendations The findings are important as they suggest the need to enhance the features for Practitioners available to female users in order to better suit their needs and desire to take control of their lives in the context of dating and/or friendship.

Impact on Society The findings reveal the need for a change of perceptions and attitudes on the part of some users to create a safer and more considerate virtual dating space, to truly achieve psychological empowerment.

Future $\quad$ More research is required on how male and female users domesticate mobile Research dating applications and how the use of these applications influence their daily lives from a socio-cultural point of view.

Keywords mobile dating applications, online dating, women empowerment

\section{INTRODUCTION}

Recently, mobile dating platforms have gained in popularity, leading to a 'digital revolution' in the modern dating scene (Hobbs, Owen, \& Gerber, 2016). People are now able to connect and interact with each other in the virtual world (Hobbs et al., 2016). The study of mobile dating applications, therefore, offers an opportunity to gain more insights into fascinating aspects of socialized behavior (Albright \& Simmens, 2013) in the virtual world. Past studies within that domain have focused mainly on how users present themselves (Birnholtz, Fitzpatrick, Handel, \& Brubaker, 2014; Ellison, Heino, \& Gibbs, 2006; Gibbs, Ellison, \& Heino, 2006), the use of deception by users of mobile dating applications (Guadagno, Okdie, \& Kruse, 2012; Toma \& Hancock, 2010; Toma, Hancock, \& Ellison, 2008) and the preferences of online daters (Akehurst, et al., 2011; Alterovitz \& Mendelsohn, 2009; Morgan, Richards, \& VanNess, 2010). Research that focuses on how female users (of all sexual orientations) experience and are affected by dating applications (Hess \& Flores, 2016; Tang, 2017) is scarce.

The study of how female users interact on mobile dating applications is particularly interesting, especially since these tools offer them the opportunity to engage in activities which might otherwise not be accessible to them through traditional means of dating (McWilliams \& Barret, 2014). Indeed, mobile dating applications have positioned themselves as tools that empower women (Mason, 2016). However, little is known on how the right set of information is made available to users at the right time so that this so-called empowerment comes about. Moreover, empowerment can take many forms (e.g., economic empowerment, psychological empowerment, etc.) and, while mobile dating applications claim to promote empowerment, the exact nature of this so-called empowerment is yet to be unpacked.

A focus on female Psychological Empowerment (PE) is particularly relevant since "a great deal of time and effort has been spent on economic empowerment, ignoring women as persons and the necessity for their psychological empowerment" (Francina \& Joseph, 2013, p.163). Moreover, social norms and biases experienced during traditional dating might also prevail in the cyber world. It is therefore important to understand how mobile dating applications that claim to challenge traditional gender roles influence female users' PE, if any. PE is also an interesting concept which warrants further investigation in relation to mobile dating as it is multi-dimensional in nature (Spreitzer, Kizilos, 
\& Nason, 1997). It is therefore interesting to investigate whether and how mobile dating applications influence the various dimensions of PE for female users. This would provide a more holistic understanding of how PE is achieved in that context.

Examples of mobile dating applications include Bumble, Tinder, Clover Dating App, OKCupid Dating amongst others. Mobile dating applications. These often share similar attributes or affordances including mobility, proximity, immediacy, authenticity and visual dominance, as identified by Chan (2017). The study specifically focuses on the Bumble application, as a case study.

Bumble is a mobile dating application, which counters traditional gender roles by requiring heterosexual women to initiate communication with their matches (Bumble, n.d.). Such tools are known as counter-heteronormative mobile dating applications. Bumble markets itself as a feminist dating application aimed at empowering women (Bumble, n.d.; Bumble, 2017).

The objective of this study is to investigate how the use of counter-heteronormative mobile dating applications creates an environment which is suitable for the PE of female users. This environment might be created through the effective and timely dissemination of relevant information to the female users within the mobile dating environment/context. This is in line with other scholars' point of view that third parties might not be able to contribute to empowerment directly but might instead create empowering conditions (e.g., Mason, 2016, Mosedale, 2005, Zimmerman, 1995). The study, therefore, investigates Bumble as a platform which provides empowering conditions (Zimmerman, 1995) for its female users. For this study, the definition of female users relates to individuals who have a female gender identity which may or may not correlate with their biological sex (Martin \& Yonkin, 2006).

The findings of this study contribute to the understanding of how the affordances and features of heteronormative mobile dating applications influence the PE of women through the timely and accurate dissemination of relevant information. The study also discusses issues around trust within a mobile dating environment and ensuing influence on PE.

The study is important as it might encourage developers to rethink the design of mobile dating applications or to retain certain features that are conducive to the PE of female users. This is particularly important as women continue to be marginalized and oppressed around the world (UN Women, 2017) and there is little certainty on how best to implement ICT initiatives that will provide the most benefits to such marginalized groups (Unwin, 2009).

The paper is organized as follows. First, a review of the literature of PE and mobile dating applications is provided. The methodology employed for the study is then discussed, followed by a description of the research findings. The paper is then concluded.

\section{LITERATURE REVIEW}

\section{MOBILE DATING APPLICATIONS}

Mobile dating applications and online dating sites are differentiated based on their affordances, but they both promote interpersonal computer-mediated communication (Sprecher, 2009). Affordances are the subjective perceptions that an object has that are based on the object's attributes (Gibson, 1979).

People typically use their desktop computers to access online dating sites, whereas mobile dating applications run on smartphones and tablets allowing users to access these apps at any time or location (Ling, 2004). Also, dating websites are usually used to connect people who live in the same broad region, while mobile dating apps are used to connect people who live in the same immediate vicinity (Chan, 2017). Users perceive online dating sites and mobile dating applications differently - users will typically use dating websites to find a long-term partner (Albright \& Simmens, 2013) while mobile dating applications have a reputation for being places to find casual sex partners (Licoppe, Rivière, \& 
Morel, 2016). However, mobile dating applications ensure a greater level of authenticity in that they require users to sign up using their existing Facebook account. Online dating applications are becoming increasingly popular with older adults (McWilliams \& Barrett, 2014), while mobile dating apps appear to be more popular with young adults in their twenties (Albright \& Simmens, 2013).

As previously mentioned, there currently exists numerous mobile dating applications on the market. Examples of popular mobile dating apps are Tinder, Grindr, Ok Cupid Dating, Coffee Meets Bagel and Bumble, with Tinder being the most popular dating app of 2017 (Emery, 2017). For the purpose of this study, two popular mobile dating applications are described and compared in relation to their affordances namely, Bumble and Tinder. The affordances include mobility, proximity, immediacy, authenticity, visual dominance (Chan, 2017) and multimediality (Ranzini \& Lutz, 2017).

Mobility refers to the ability of a user to log onto the application via their smartphones anywhere and anytime (Chan, 2017). Proximity relates to the fact that users can connect to other people who are in their immediate vicinity through the application (Chan, 2017). Immediacy relates to the mobile dating application's ability to provide "fast sexual encounters" (Liccoppe et al., 2016, p. 2545). A mobile dating application allows for Authenticity when users are required to register with a Facebook account (Chan, 2017). Visual dominance is achieved through the prevalent use of pictures within the mobile dating application (Chan, 2017). Multimediality allows users to link several social media accounts (e.g., Facebook, Instagram etc.) to their mobile dating account (Ranzini \& Lutz, 2017).

Bumble is a mobile dating application that markets itself a tool that promotes women empowerment. As stated on the Bumble website: "We empower women by giving them the ability to control the conversation when dating, finding friends, and networking online" (Bumble, n.d). Users can utilize the platform to find romantic partners, friends or to build their careers. Bumble requires that women initiate contact with their matches and claims that this prerequisite has resulted in the highest chat rate of matched users in the industry and a low number of reported incidents of harassment and abuse (Bumble, n.d.). As of July 2017, Bumble had a user base of 18 million people (Tepper, 2016) with about 55\% of these users being women (Burke, 2015). Women between the ages of 18 to 25 are the largest group of female Bumble users and makeup $60 \%$ of the application's female population, while women between 25 and 35 are the second largest group (Burke, 2015).

Tinder is currently regarded as the most popular dating application with a minimum of ten million active users a day (James, 2015). Sean Rad and Justin Mateen founded Tinder at the University of Southern California in September 2012. Tinder grew from three hundred to one thousand users within a week (James, 2015).

Table 1. Tinder and Bumble Affordances

\begin{tabular}{|l|c|l|}
\hline Affordances & Bumble & Tinder \\
\hline Mobility & $\mathrm{X}$ & $\mathrm{X}$ \\
\hline Immediacy & $\mathrm{X}$ & $\mathrm{X}$ \\
\hline Proximity & $\mathrm{X}$ & $\mathrm{X}$ \\
\hline Authenticity & $\mathrm{X}$ & $\mathrm{X}$ \\
\hline Visual Dominance & $\mathrm{X}$ & $\mathrm{X}$ \\
\hline Multimediality & $\mathrm{X}$ & $\mathrm{X}$ \\
\hline
\end{tabular}

Both Bumble and Tinder offer similar affordances as shown in Table 1. They both encourage women to interact with the tool from various locations through their smartphones or tablets in private, public and semi-public spaces (mobility) provided that there is an internet connection (Rocha Santos, 2018). Both tools alert their users of new matches or messages quickly, allowing for immediacy. It has been argued that Tinder's high degree of immediacy can lead to users being overloaded with information and distraction from the real world (Rocha Santos, 2018). The proximity feature of Bumble 
and Tinder also enables users to interact with users who are close by. For example, Tinder users must enable the location services on their cellphones to access these features (Rocha Santos, 2018).

Authenticity is an important aspect of mobile dating, and both Tinder and Bumble rely on Facebook to cross-check the authenticity of the users (MacLeod \& McArthur, 2018). Both Tinder and Bumble are visually dominant mobile dating applications. However, MacLeod and McArthur (2018) state that photos are more prominent in Bumble profiles compared to Tinder. For example, in Bumble, photos can be used as background images whilst displaying other relevant information specified in a user's profile. Both apps support the multimediality affordance by allowing users to connect to other social media profiles such as Instagram and Facebook. While both Tinder and Bumble offer similar affordances, the study focused on Bumble as it specifically positions itself as a feminist dating application that empowers women (Bivens \& Hoque, 2018).

\section{EMPOWERMENT}

Empowerment is both a principle of community service and a theoretical framework to understand the processes and efforts that people go through to exercise control in their lives and the consequences thereof (Zimmerman, 2000). Empowerment theory seeks to measure empowerment in different situations and environments, to examine empowering processes and to create a distinction between empowerment and other similar variables, such as self-esteem, self-efficacy or locus of control (Zimmerman, 2000). Empowerment theory is based on Rappaport, Swift, and Hess's definition and is thus analyzed at three levels, namely psychological empowerment, organizational empowerment and community empowerment (Zimmerman, 1995). All three levels of empowerment are assessed using different compositional criteria and are interdependent on one another (Zimmerman, 1995).

Psychological empowerment is different for different people and is different in different contexts (Zimmerman, 1995). Zimmerman (1995, p.586) also posits that psychological empowerment "varies in different life domains (e.g., work, family, recreation)." Psychological empowerment can also be perceived as fluctuating over time.

As a theory, empowerment can be described as both a process and an outcome (Stromquist, 2015; Zimmerman, 2000). This implies that processes such as actions, activities, structures (e.g., gaining power, securing necessary resources, understanding one's socio-political environment) can be empowering and the outcomes of these processes can result in one attaining some level of empowerment (Zimmerman, 2000).

\section{PSYCHOLOGICAL EMPOWERMENT}

Different people experience psychological in different ways. This means that the process and meaning of psychological empowerment are affected by an individual's traits. Psychological empowerment is a changeable condition which increases and decreases at different points in time (Zimmerman, 1995). Zimmerman's (1995) nomological network of psychological empowerment combines the assessment of intrapersonal variables, interactional variables, and behavioral variables as influences on empowerment of the individual.

\section{Intrapersonal variables}

The intrapersonal variables of psychological empowerment relate to how people think about themselves. This specifically includes domain-specific perceived control and self-efficacy, motivation to control, and perceived competence (Zimmerman, 1995). It is the emotional component of psychological empowerment which focuses on a person's feelings about their inner world (Kasturirangan, 2008). Table 2 provides a description of each intrapersonal variable. 
Mobile Dating Applications and Psychological Empowerment

Table 2. Descriptions of intrapersonal variables of psychological empowerment

\begin{tabular}{|l|l|}
\hline Intrapersonal variable & Description \\
\hline $\begin{array}{l}\text { Domain-specific } \\
\text { perceived control }\end{array}$ & $\begin{array}{l}\text { A person's belief in their ability to influence the different spheres of } \\
\text { their lives such as family, work, or socio-political environments } \\
\text { (Paulhus, 1983) }\end{array}$ \\
\hline $\begin{array}{l}\text { Domain-specific } \\
\text { self-efficacy }\end{array}$ & $\begin{array}{l}\text { A person's belief in their ability to perform tasks that will enable then } \\
\text { to attain specific outcomes (Bandura, 1977) }\end{array}$ \\
\hline Motivation to control & $\begin{array}{l}\text { A person's need to exert control in a domain of their life } \\
\text { (Zimmerman, 1995) }\end{array}$ \\
\hline Perceived competence & A person's belief in their ability to achieve success (Nicholls, 1989) \\
\hline
\end{tabular}

Although they are not depicted in the nomological network of psychological empowerment, perceptions of social isolation, powerlessness, normlessness (Zimmerman, 1990; Zimmerman \& Rappaport, 1988), and helplessness (Rappaport, 1984) are other intrapersonal variables which would be expected to impact psychological empowerment negatively.

\section{Interactional variables}

The interactional variables of PE refer to how people understand their community and the sociopolitical issues within that community (Zimmerman, 1995). Table 3 provides a description of each interactional variable. While intrapersonal variables are concerned with an individual's perceived control, interactional variables go one step further and relate to the actual steps that can be or are taken to exert control (Zimmerman, 1995).

Table 3. Descriptions of interactional variables of psychological empowerment

\begin{tabular}{|l|l|}
\hline Interactional Variables & Description \\
\hline Critical awareness & $\begin{array}{l}\text { The understanding of what are the resources required to achieve a } \\
\text { goal, how to achieve the relevant resources and the skills needed } \\
\text { to manage the resources (Kieffer, 1984) }\end{array}$ \\
\hline Understanding causal agents & $\begin{array}{l}\text { The awareness of the factors that may influence, inhibit or en- } \\
\text { hance one's efforts to exert control in the socio-political environ- } \\
\text { ment (Sue \& Zane, 1980). }\end{array}$ \\
\hline $\begin{array}{l}\text { Skill development (decision } \\
\text { making, problem-solving and } \\
\text { leadership skills) }\end{array}$ & $\begin{array}{l}\text { People's understanding of the skills needed to help them be inde- } \\
\text { pendent and to control events in their lives (Zimmerman, 1995). }\end{array}$ \\
\hline $\begin{array}{l}\text { Skill transfer across life do- } \\
\text { mains }\end{array}$ & $\begin{array}{l}\text { The transfer of the skills that people have acquired in one context } \\
\text { to other spheres of the lives (Zimmerman, 1995). }\end{array}$ \\
\hline Resource mobilization & $\begin{array}{l}\text { The ability to rally the required resources to achieve a goal (Zim- } \\
\text { merman, 1995) }\end{array}$ \\
\hline
\end{tabular}

\section{Behavioral variables}

The behavioral component of PE describes actions that are taken to influence outcomes (Zimmerman, 1995). Table 4 provides a description of each behavioral variable. 
Table 4. Descriptions of behavioral variables of psychological empowerment

\begin{tabular}{|l|l|}
\hline Behavioral variables & Description \\
\hline Community involvement & $\begin{array}{l}\text { A person's involvement and participation in community- } \\
\text { action activities (Christens, Peterson, \& Speer, 2011). }\end{array}$ \\
\hline Organizational participation & $\begin{array}{l}\text { A person's participation in important organisational tasks } \\
\text { (Zimmerman, 1995). }\end{array}$ \\
\hline Coping Behaviors & $\begin{array}{l}\text { A person's own effort to solve personal and interperson- } \\
\text { al problems with the aim of mastering, minimizing or } \\
\text { tolerating stress and conflict (Weiten, Dunn, \& Hammer, } \\
\text { 2014). }\end{array}$ \\
\hline
\end{tabular}

Together, the three main components of Psychological Empowerment put forward by Zimmerman (1995), help us understand how a person perceives their ability to be empowered (intrapersonal components), their understanding of how their environment operates and what are the resources and skills available to them (interactional components) and the actual steps that they take to exert control (behavioral components).

\section{SOCIAL MEDIA AND WOMEN EMPOWERMENT}

Studies have shown that dating online affords people the freedom to step outside the normal gender roles of dating (Merkle \& Richardson, 2000). For young women, dating online allows them to be assertive and claim power in heterosexual relationships without moving outside of their realms of comfort (Clark, 1998). It is, however, uncertain whether this power translates into changed gender roles and expectations outside of cyberspace (Clark, 1998). Moreover, mobile dating and online dating are different, and the question still arises as to whether mobile dating has contributed to changed gender roles and empowered women. The few studies conducted on mobile dating and women empowerment have even shown that with mobile dating, gender roles are not necessarily changed. For example, Lopes and Vogel (2017) found that there is a link between the design of the interface and the sexist behavior experienced by female users. These sexist behaviors reinforce gender patterns that threaten women's empowerment, their confidence and reinforce the notion that women can be seen as sexual objects (Lopes \& Vogel, 2017). However, that study did not specifically explore empowerment, let alone psychological empowerment as a multi-dimensional concept. Further research is therefore needed to understand better how the various facets of psychological empowerment are impacted when women use mobile dating applications like Bumble.

Dating online also allows women to take a more active role in romantic interactions without jeopardizing their privacy and safety (Danet, 1998). For example, women can easily end communication with individuals they consider threatening (Scharlott \& Christ, 1995). Women are more likely than men to end communication with someone who flirted with them in a way that made them feel uneasy (Smith \& Duggan, 2013). However, it is unclear as to whether this can be considered psychological empowerment from the perspective of the female users. Further studies are needed to ascertain what types of interactions through mobile dating applications influence psychological empowerment.

Privacy can be a concern for users of mobile dating apps, particularly for those who come from certain communities and live certain lifestyles, such as women who are part of the LGBTQI+ community or those seeking casual sex (Blackwell, Birnholtz, \& Abbott, 2015). While homosexuality and promiscuity have gained broader acceptance (Hirshman, 2012), some users may still fear the stigma associated with being labeled as not being heterosexual (Dodge, Jeffries, \& Sandfort, 2008). While mobile dating applications claim to accommodate users of all sexual orientations and gender, little is known on the extent to which these users, particularly female users, feel empowered while engaging 
on the platform. It is unclear as to whether they still face stigma from society or other users. Further studies are therefore needed to investigate the matter.

Stavrositu and Sundar (2012) believe that social media platforms are gradually tapping into the Internet's claimed ability to empower. This is supported by Hamid, Ishak, and Yusof, (2016) who claim that social media plays a part in enabling women to gain control over their lives as well as improve its quality, which is in line with the definition of psychological empowerment provided by Tahir and Rana (2013). Women feel that social media can be used to improve their levels of self-confidence, resilience (Hamid et al., 2016) and gain peace of mind (Hamid et al., 2016; Stavrositu \& Sundar, 2012). Mobile dating applications (e.g., Bumble and Tinder) are often referred to as social media platforms (Mason, 2016). Therefore, based on past studies, mobile dating applications can potentially promote women empowerment. However, while studies have extensively focused on other forms of social media (e.g., Facebook and Instagram) and have established that these can contribute to empowerment, studies that investigate mobile dating applications and their specific contribution to the psychological empowerment of female users is still scarce. While still being a form of social media platform, mobile dating applications have unique features and rely on unique forms of interactions between users that might influence psychological empowerment in various ways and are worth investigating.

\section{METHODOLOGY}

This section describes the methodology followed for the study. The rationale for the research design is detailed, with a particular focus on the choice between a qualitative vs. quantitative study, the case study design, the research instrument design, the sampling strategy and how the data analysis was conducted.

\section{QUALITATIVE VS. QUANTITATIVE}

The study was qualitative, cross-sectional and deductive in nature. A qualitative study was relevant as it encouraged participants to reflect on their responses and elaborate whenever required (Saunders, Lewis \& Thornhill, 2011). A qualitative approach also allowed the researchers to look for deep insights into the use of Bumble and its ability to nurture psychological empowerment.

\section{CASE STUDY DESIGN}

The research approach was that of a single case study. This method was deemed particularly useful as it allows for "how" and "why" questions to be answered (Yin, 2013) while also taking the context of the studied phenomenon into consideration (Baxter \& Jack, 2008). Case study research is additionally suitable for understanding the intricate and pervasive relations between organizations, technologies, and people (Dubé \& Paré, 2003). By conducting a case study, a deep understanding of the phenomena was therefore obtained (Gustafsson, 2017). In particular, the chosen case was that of Bumble, and the unit of analysis was the female Bumble users.

\section{RESEARCH INSTRUMENT DESIGN}

The research instrument was derived from the theoretical framework and was divided into four sections. The questions were also structured and derived based on Mosedale's (2005) recommendations on how to study women empowerment.

Section 1 of the research instrument pertained to the uses and gratifications of the Bumble app. In particular, the female users' motivations for use, uses, and benefits of the Bumble app are explored. Section 2 identified the constraints a female user encounters while using the Bumble app. In Section 3 the development of the female users' agency was explored while the ways in which this agency is used to overcome constraints was looked at in Section 4. This format allowed for the information gathered to be structured according to the research model. 
The research instrument and interview agenda were provided to each participant before the interview. This allowed the participants to prepare and reflect on the questions in advance and provide more thought-through answers.

\section{SAMPLING STRATEGY}

Self-selection sampling is the non-probability technique that was used for this study. The researchers publicized the need for participants by creating a profile on the Bumble app for this purpose. People who wished to take part in the study then contacted the researchers on their own accord. This sampling method was preferred because it allowed for data to be gathered quickly and ensured a greater likelihood that participants were willing, committed and enthusiastic about participating in the research (McLeod, 2014).

Ten respondents were interviewed for the study before saturation was reached. Table 5 outlines the demographics of the participants who chose to take part in the study.

Table 5. Research participants

\begin{tabular}{|l|l|l|l|}
\hline Interviewee & Age & Nationality & $\begin{array}{l}\text { Sexual orienta- } \\
\text { tion }\end{array}$ \\
\hline A & 21 & Ukrainian & Bisexual \\
\hline B & 21 & South African & Heterosexual \\
\hline C & 19 & South African & Heterosexual \\
\hline D & 23 & South African & Heterosexual \\
\hline E & 22 & Namibian & Heterosexual \\
\hline F & 21 & South African & Heterosexual \\
\hline G & 26 & South African & Pansexual \\
\hline H & 30 & Swiss & Heterosexual \\
\hline I & 20 & South African & Heterosexual \\
\hline J & 23 & South African & Heterosexual \\
\hline
\end{tabular}

It must be noted that all of the participants were cisgendered women and that, although the researchers made a point to invite women who were not cisgendered to partake in the research, none responded. According to Aultman (2014, p.61), the term cisgender is used to "describe individuals who possess, from birth and into adulthood, the make or female reproductive organs (sex) typical of the social category of man or woman (gender) to which that individual was assigned at birth.”

In the past, bisexuality was defined as an attraction to two genders. However, as our understanding of gender and sexual fluidity progresses, this definition is being redefined to describe the "attraction to any two or more genders" (Coletta, 2018, p. 87). This implies that the lines between bisexual and pansexual is more and more blurry. Indeed, pansexuality can be applied to people who "are romantically, cognitively, and/or sexually attracted to all genders and sexes" or lack thereof (Gonel, 2013, p. 36).

\section{DATA ANALYSIS APPROACH}

The data were analyzed using thematic analysis. Thematic analysis is a method for "identifying, analyzing, and reporting patterns (themes) within the data" (Braun \& Clarke, 2006, pp. 79). The process of thematically analyzing data was divided into six phases, namely familiarisation with the data, initial code generation, searching for themes, reviewing themes, defining and naming themes and producing the reports. This technique was applied deductively by collating codes into themes based on the concepts from Zimmerman's (1995) nomological network for psychological empowerment. 


\section{FINDINGS}

This section describes the findings of this study. The findings are structured according to the components of Psychological Empowerment identified by Zimmerman (1995), namely, the influence of Bumble on intrapersonal variables of Psychological Empowerment, the influence of Bumble on interactional variables of Psychological Empowerment, and the influence of Bumble on behavioral variables of Psychological Empowerment.

\section{THE INFLUENCE OF BUMBLE ON INTRAPERSONAL VARIABLES OF PSYCHOLOGICAL EMPOWERMENT}

\section{Domain specific perceived control}

Domain-specific perceived control relates to a person's belief in their ability to influence the different spheres of their lives (Paulhus, 1983). Participants of this study indicated that they used Bumble to meet new people to either make friends or find a romantic partner. Consequently, in this study, domain-specific control was interpreted as the female users' ability to influence spheres of their lives relative to friendship or romantic relationships.

The findings of this study indicate that Bumble supports female users' Domain Specific Perceived control because of their ability to initiate conversations with their matches and by blocking them if required.

Swiping left and initiating conversations. The act of swiping left and eventually initiating conversations is a strong feature which enables female users to choose who they wish to engage with. This leads to a feeling of perceived control of the situation and what will happen in future interactions. Moreover, it is interesting to note how this feeling of being in control can grow over time, as they continuously engage in such behaviors.

It's still a new thing you know, but I think the more I do it, I'll feel secure with time and also it's just a matter of realizing that I'm not breaking any law by approaching a guy. I'm just me with my agency, just going for what I want you to know. (Participant B)

Un-matching functionality. The ability to block and un-match certain people also contributed to the participants' perceived feeling of control. Bumble application has enabled some female users to stand up for myself and be able to tell a person, okay well you're frustrating me, I'm going to delete you, bye (Participant G).

The availability of relevant functionalities to support the initiation of conversations by female users, swiping left, un-matching or blocking people implies that Bumble is a tool that promotes empowerment as a process (Stromquist, 2015; Zimmerman, 2000). The tool provides some resources to female users which enable them, to some extent, to take control of how they wish to interact with potential partners in the online dating scene.

Un-matching unwanted users could also be seen as a way for the female users to manage perceived risks inherent to online dating. As stated by McWilliams and Barrett (2014), control is a major issue during computer-mediated communication and for female users, being able to control with whom they communicate with, is empowering. There are risks and uncertainties associated to online dating (Hallam, Walrave, \& De Backer, 2018) and Bumble appears to provide relevant functionalities (e.g., un-matching), to enable female users to control and avoid risky situations.

The features specific to swiping as well as blocking and un-matching are typical of other mobile dating applications (e.g., Tinder). This implies that other mobile dating applications with similar features will also achieve perceived control of female users. 


\section{Domain specific self-efficacy}

Ability to initiate conversations. Domain-specific self-efficacy relates to a person's belief in their ability to perform tasks that will enable them to attain specific outcomes (Bandura, 1977). For the participants of the study, self-efficacy manifested itself in their ability to initiate conversations with strangers as a means to perhaps form friendships or romantic relationships with them. However, the participants expressed mixed feeling relating to their self-efficacy in being comfortable to communicate (i.e. send messages) with matches. For example, some participants had no inhibitions in sending comments or compliments to potential matches. There even seemed to be a sense of detachment while doing so.

If I feel like sending a comment because of their profile or like a compliment or whatever, just send it not like think abead and move on. (Participant A)

Some however reported that they, at times, found it awkward to have to initiate conversations and would have preferred not always to have to message first. Some of those who did not feel comfortable perceive that they ought to get better at it.

Because I would say, let's, if there is a match, I don't always want to bave to message them I want them to also be able to message me, but it is, it's not like a major problem but it is something that I found a bit of a challenge. (Participant D)

This indicates that the sole availability of relevant functionalities (e.g., functionality to enable women to initiate conversations) is not enough to promote empowering processes. This is in line with other studies that found that a techno-centric approach to empowerment is not enough (Servaes \& Hoyng, 2017). As mentioned by Servaes and Hoyng (2017, p. 257), technology is "caught up in complex cultural matrices" and cannot be considered as something that can cause social effects. The findings reveal that gender roles and expectations can still prevail online in spite of access to certain resources to circumvent these. Other mobile dating applications like Tinder that do not require women to initiate conversations might be better suited for female users who are not comfortable or who do not have enough self-efficacy to do so. However, these other mobile dating applications might not have the necessary features to promote self-efficacy explicitly.

\section{Motivation to control}

Bumble's reputation. Motivation to control relates to a person's need to exert control in a domain of their life (Zimmerman, 1995).

Some of the participants expressed an inherent need to take control of their dating life, either through the need to control the unsolicited messages that they receive online or to have a more positive experience through an app which is well designed. Bumble's reputation as a pro-women empowerment app nurtured this motivation, and some participants explained that they chose the Bumble application because of its reputation for enabling these needs.

Because of the positive vibes it gave out, and because of the "Oh look, empowerment," and because of the bope that you won't be spammed as much, and I think it just in general had a more positive vibe with its yellow look and Bumble sounded happier and nicer. (Participant A)

Hamid et al. (2016) stated that social media has the ability to enable women to take control and improve the quality of their lives. The study found that female users were aware of this reputation when it comes to Bumble, which further informed their decision relative to their choice of an online dating application.

This indicates that in addition to trusting the credibility of the potential partner, trust in the reputation of the mobile dating platform is also needed. Metzger and Flanagin (2013) found that users tend to trust a source that they recognize as being more credible compared to others, even if they have not verified the content of the site or their credentials. To some extent, this is recognizable in the 
Mobile Dating Applications and Psychological Empowerment

study as female users were attracted to the Bumble's user interface and the general branding associated with the Bumble application. Other mobile dating applications have not explicitly branded themselves as a feminist application. But they each have other labels to attract users, based on their specific needs. It is therefore possible that, when the users' preferences are aligned with the mobile dating applications' reputation, users might feel more in control.

\section{Perceived competence}

Perceived competence relates to a person's belief in their ability to achieve success (Nicholls, 1989). According to the participants, Bumble can both generate feelings of self-doubt or self-confidence pertaining to female users' perceived attractiveness levels.

Self-doubt. Unless the female user has the ability to reflect, the study found that not getting any matches can have a negative impact on their perceived competence, resulting in self-doubt. For example, one participant explained that her initial reaction to not having matches was a feeling of inadequacy and of being undesirable. Others reported that it made them sad: "that is pretty sad because I see a lot of cute guys and I'm swiping and - yeah, that is sad" (Participant C). There is thus a risk of people's feeling of self-worth being tied to the number of matches obtained.

When I wasn't getting matches I started feeling like there's something wrong with me, like when people look at my profile do they not feel the need to match up with me. So, when I wasn't getting any matches I was worried that people look at me, men look at my profile and think, we're not interested and then when I started getting matches, I thought I was desirable. Which kind of makes me feel like why does my desirability depend on whether men on Bumble see me attractive or not. So I had to just like just pause and think about the fact that even if I don't get matches, I still am desirable you know. (Participant B)

The feeling of self-doubt could, therefore, be overcome through reflection on the part of the user. For instance, participants who felt that there might be many reasons behind why they do not get a match did not feel negatively impacted.

I don't really feel offended because maybe I don't know how exactly it works, maybe I swipe right but they haven't seen my profile, and they swipe left, doesn't bother me really because everyone has their own preferences. (Participant D)

Self-confidence boost. Some respondents reported a boost of self-confidence in relation to their attractiveness level when they receive a match on Bumble. The application, therefore, appeared to reinforce female users perceived competence.

It does somewhat boost your confidence in a way, when you see okay these people or they like me when they swipe right and things so in a way maybe it makes you feel a bit attractive or whatever. (Participant D)

Even without inherent self-esteem issues, some participants expressed that it was pretty cool to get a match.

Past studies have also found that social media can improve the level of self-confidence and resilience of women (Hamid et al., 2016) and that repeated rejection can further reduce a person's feeling of self-perceived mate value (Charlot, 2018) However, this current study further suggests that depending on the female users' point of view or personality, self-confidence can either be boosted or reduced. This finding is applicable to other mobile dating applications that also rely on the 'swiping' feature to trigger a match.

In the context of computer-mediated dating environments, users are motivated to control how they represent themselves and the impression they create on others to achieve their goal (Ward, 2017). Since this study ascertained that self-doubt could be incurred when this goal is not achieved, future research is needed to investigate the relationship between self-doubt and unsuccessful self-

presentation. 
A summary of the findings relative to Bumble and Intrapersonal variables of psychological empowerment is shown in Figures 1 and 2. From an Informing Science perspective, it can be argued that the features of the Bumble application allow women to access relevant information on potential matches which they can use to initiate conversations with or un-match people. Access to information about Bumble's reputation is also relevant. However, in line with Cohen's Informing Science framework (Cohen, 2009), the psychological fragilities of the receiver (i.e., the women) influence how the information is received and their resulting feeling of perceived competence.

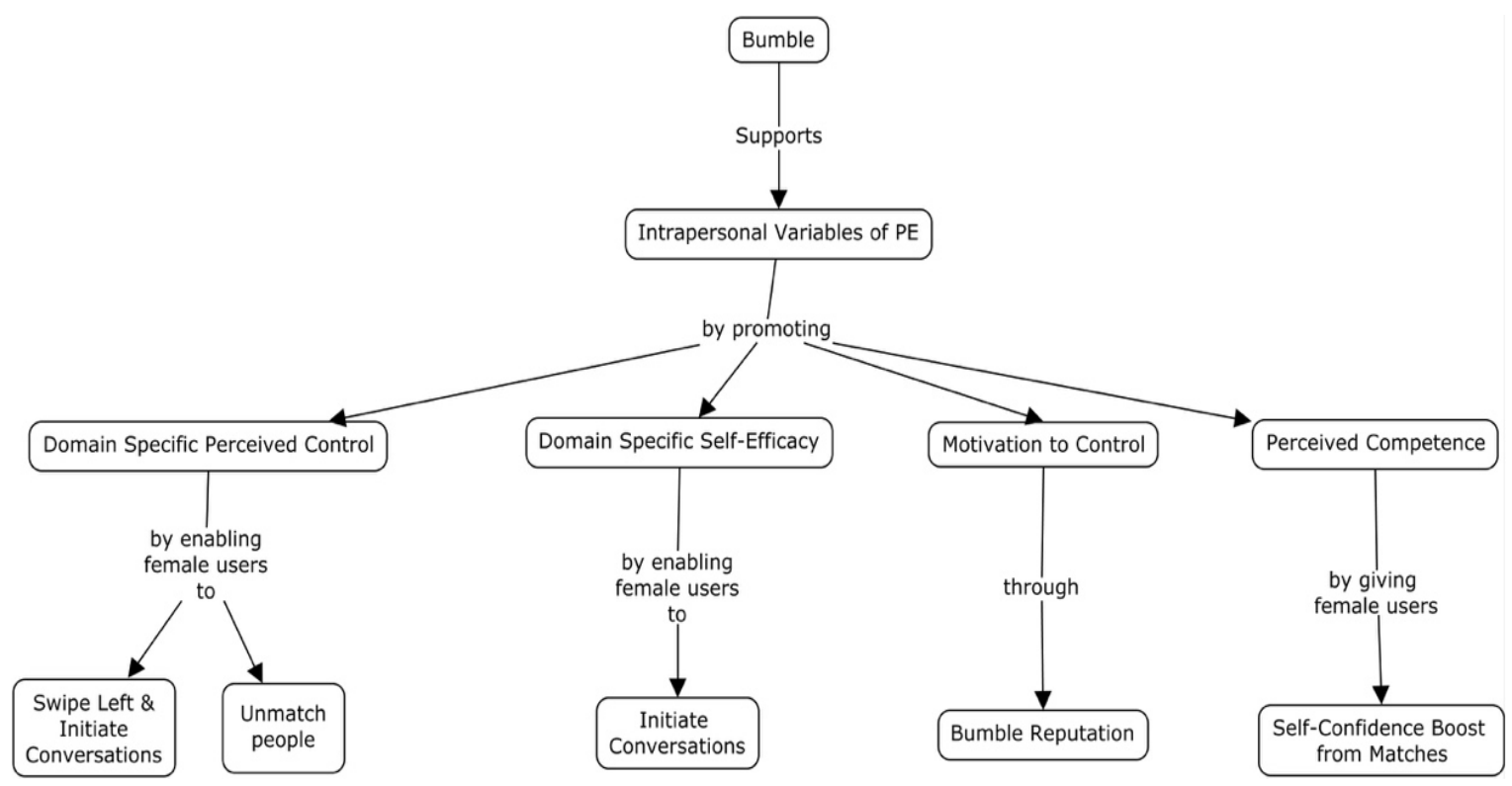

Figure 1. Bumble's supported Intrapersonal Variables of PE

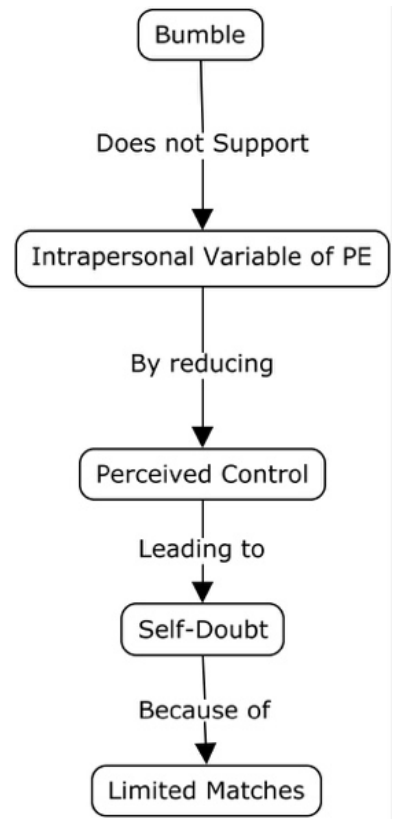

Figure 2. Bumble's unsupported Intrapersonal Variables of PE 


\section{THE INFLUENCE OF BUMBLE ON INTERACTIONAL VARIABLES OF PSYCHOLOGICAL EMPOWERMENT}

Interactional variables of psychological empowerment relate to understanding and learning about one's environment and include preparatory stages to actual participation. Hence, in the context of the study, it relates to how Bumble allows female users to better understand their world in relation to dating or friendship seeking, in order to take further measures to be truly psychologically empowered in the dating or friendship scene.

\section{Critical awareness}

Critical Awareness relates to the understanding of the resources required to achieve a goal, how to achieve the relevant resources and the skills needed to manage the resources (Kieffer, 1984). After having used Bumble or other similar mobile dating applications, participants became aware of the need to "screen" potential matches before initiating conversations.

Awareness of the need to "screen" potential matches. In the study, female users were aware of the need to understand people's genuine motivations for using the application before trusting anyone or being emotionally involved. They were aware of the need to "screen" matches to see if they are indeed someone they wish to interact with. However, the only way for them to do so is by looking at the Bumble profiles and by asking relevant questions to ascertain people's credibility. Some paid attention to the content of the personal bios, in the hope of finding "quirky" details that would allow for conversation starters.

I think just by looking at the person's profile you're able to tell if this person is what you want or not. So I think the first steps are just looking at the profile and just try to analyze it and see who this person is and if you want to take it further not. (Participant B)

The need to "screen potential matches" could be perceived as a form of uncertainty reduction mechanism, which is driven by privacy-related concerns (i.e., personal security, misrepresentation, and recognition) and self-efficacy (Gibbs, Ellison, \& Lai, 2011; Hallam et al., 2018). Risks related to privacy are inherent in online dating. As other mobile dating applications operate similarly, female users would also need to screen potential matches on other platforms. This, together with the pressure to disclose personal information in order to increase their chances of forming romantic relationships, leads to such uncertainty reduction behaviors (Gibbs et al., 2011; Hallam et al., 2018).

During online and mobile dating, the possibility for misinformation is a challenge faced by many users. Misinformation occurs when there is a discrepancy between what is being said and the reality being referenced (Wang \& Lu, 2007). Deception is also another concern faced by users in the online dating sphere. According to Markowitz and Hancock (2018), deception is a deliberate attempt by one party to generate a false belief in another party. During online dating, deception occurs when a user deliberately misrepresents social information resulting in discrepancies between their online and offline appearances. The study re-affirms the fact that it is difficult for female users, to detect misinformation (Wang and Lu, 2007) and deception (Markowitz \& Hancock, 2018), determine the veracity of information and develop trust over the internet. Female users involved in mobile dating expressed the need to evaluate the motivations of their potential matches. While the first level of trust (i.e., cooperative intention) is already established (i.e., willingness to engage in mobile dating), the female users feel the need to screen users' personal bios and profiles to achieve the second level of trust namely trust of content.

\section{Understanding causal agents}

Understanding causal agents relates to one's awareness of the factors that may influence, inhibit or enhance their efforts to exert control in the socio-political environment (Sue \& Zane, 1980). In the context of the study, these factors relate to physical appearances, society's influence, and men's negative judgment. 
Physical appearance. Respondent explained that they were aware of the importance of "looking good" and "being confident" in order to meet people, which further influenced their confidence level.

Oh, it's just, just looking good, I don't know if it's like a thing like because if you look good and confident and you able to approach whoever you want to. So yeah, I think, I don't know if that counts as assistance but it definitely influenced the way I feel and my confidence as well. So if like I'm looking good today, so I can do whatever. (Participant B)

Realizing the importance of 'looking good and confident' could lead to some degree of deception during the 'profile stage' of mobile/online dating. The 'profile stage' relates to the period where users create their personal profile with the aim of depicting themselves in the best possible manner (Markowitz \& Hancock, 2018). Markowitz and Hancock (2018) explain that the use of deception during this phase is instrumental for users to achieve their self-representation goals. Since other mobile dating applications heavily rely on users' pictures to entice them to swipe left or right and trigger a match, physical appearance is a causal agent which is valid for other platforms.

Society's influence. Some participants were aware of the fact that society might have played a role in their perceptions of gender stereotypes in a relationship as well as safety issues. They also said that society influenced the perceptions of other users with whom they interact via the Bumble application.

Society has somehow made me believe that I should be waiting for the guy to do something. (Participant B)

Men's negative judgment. In some cultures, women are not supposed to approach men. If they do so, they are judged negatively. Therefore, even if the Bumble application seeks to encourage women to approach men with the aim of empowering them, the participants explained that they are nonetheless aware of the need to be careful when choosing the type of men they wish to initiate conversations with.

From where I come from, you are being a whore for approaching a man. So at home, I would feel shameful to do it, and the guy as well would treat me like a whore because I approached him. So ends up saying that I have to be also careful like I have to think. about the person I'm approaching and being mature enough to actually to acknowledge the fact that I have agency, I can do whatever I want and you know it doesn't say anything about my character or how many guys have said good, it's just me approaching you and going for what I want. (Participant B)

Past studies have found that online dating allows female users to be assertive and claim power in heterosexual relationships without moving outside of their realms of comfort (Clark, 1998). However, these studies stated that it is uncertain whether this power translates into changed gender roles and expectations outside of cyberspace (Clark, 1998). This current study found that some women are still constrained by society's influence and judgment, making it difficult for them truly to claim power. This implies that gender roles are not necessarily truly changed, even through the use of a mobile dating application that seeks to promote this change. While Bumble explicitly requires women to make the first move, it is not the case in other mobile dating applications, thus mitigating the risk of facing men's negative judgment.

\section{Skills development}

Skills development relates to people's understanding of the skills needed to help them be independent and to control events in their lives (Zimmerman, 2000). In the context of the study, the skill had to be developed according to the participants, is the ability to make the first move online.

Ability to make the first move online. The ability to make the first move was described as an empowering feeling, and some female users reported that they had acquired such skills through Bumble. Female users reported that they felt autonomous in contrast to what is the case in more traditional settings (i.e., face to face). They felt control over their dating life and enjoyed being out of their com- 
Mobile Dating Applications and Psychological Empowerment

fort zone. Terms like "courage" and "bravery" were also used to describe how they felt about the interactions.

I think it gives autonomy because as the girl you bave to make the first move otherwise notbing is going to happen. Normally in any traditional setting, you'd expect the guy to "make the move." So with Bumble, it's different, you have to "make the move" as a woman. So it's like OK well I have this power thing. (Participant E)

For those who were able to make the first move online, it can be stated that Bumble promoted empowerment as a process (Stromquist, 2015; Zimmerman, 2000). The act of "making the first move" is an empowering action (i.e., a process), which can result in a feeling of empowerment. As previously stated, other mobile dating applications do not explicitly require women to make the first move. On these other platforms, women might instead choose to do so, resulting in fewer opportunities for skills development.

\section{Skills transfer across life domains}

Ability to initiate conversations offline. some participants reported that upon having used bumble, they now feel capable of approaching someone face to face and inviting them for a drink.

Ob definitely, yeah. Like I don't really have a fear of rejection, but yeah so and I'm like you know what I'm going to approach you, let's have drinks. If you don't like me, if you don't dig me that way, it's okay, let's go on with our lives and like have fun. (Participant E)

Others, on the other hand, felt that this was impossible, because of society's judgment.

Well, no. (laughter) No, no way. I don't think I have the guts to do that. I think the app helped me do that, but I don't think. I'll do that personally on my own without the app... I mean, come on, the society we live in - I mean, no girl approaches the guy. That's how we are. That's how I think we are. So, I don't think I'd be able to do that. So, I don't think - no. No way. (Participant C)

This finding implies that in some cases, Bumble can promote empowerment as a process (Stromquist, 2015; Zimmerman, 2000) which transcends beyond the application itself. It can be posited that other similar mobile dating platforms might also allow such skills to be nurtured for some women who are so inclined.

\section{Resource mobilisation}

Resource mobilization relates to the ability to rally the required resources to achieve a goal (Zimmerman, 1995). In the context of the study, the goal of the participants was either to form romantic relationships or new friendships. In that regard, the mobile dating application was seen as resources by the participants. For example, one participant reported that upon having used Bumble and having received matches, she has also downloaded Tinder in order to maximize her chances of meeting people as face to face interactions were not effective for her.

So I downloaded Tinder as well. So I think, so because meeting like men like just in real life wasn't working for me, so I thought let me just explore well other places. So the fact that I had matches on bumble it kind of gave me a little hope that I might actually meet more people, so I downloaded another app tinder and actually being matching. (Participant B)

Others had discovered that other dating applications did not suit their needs and instead decided to download Bumble to meet more suitable people. One participant even found that she actually did not enjoy the use of mobile dating applications and that the tool would never help her to meet someone for a relationship. She eventually deleted the Bumble application.

Maybe in realizing that I actually don't like dating apps and that I'm probably not going to speak to anyone on them like seriously to meet someone. (Participant A) 


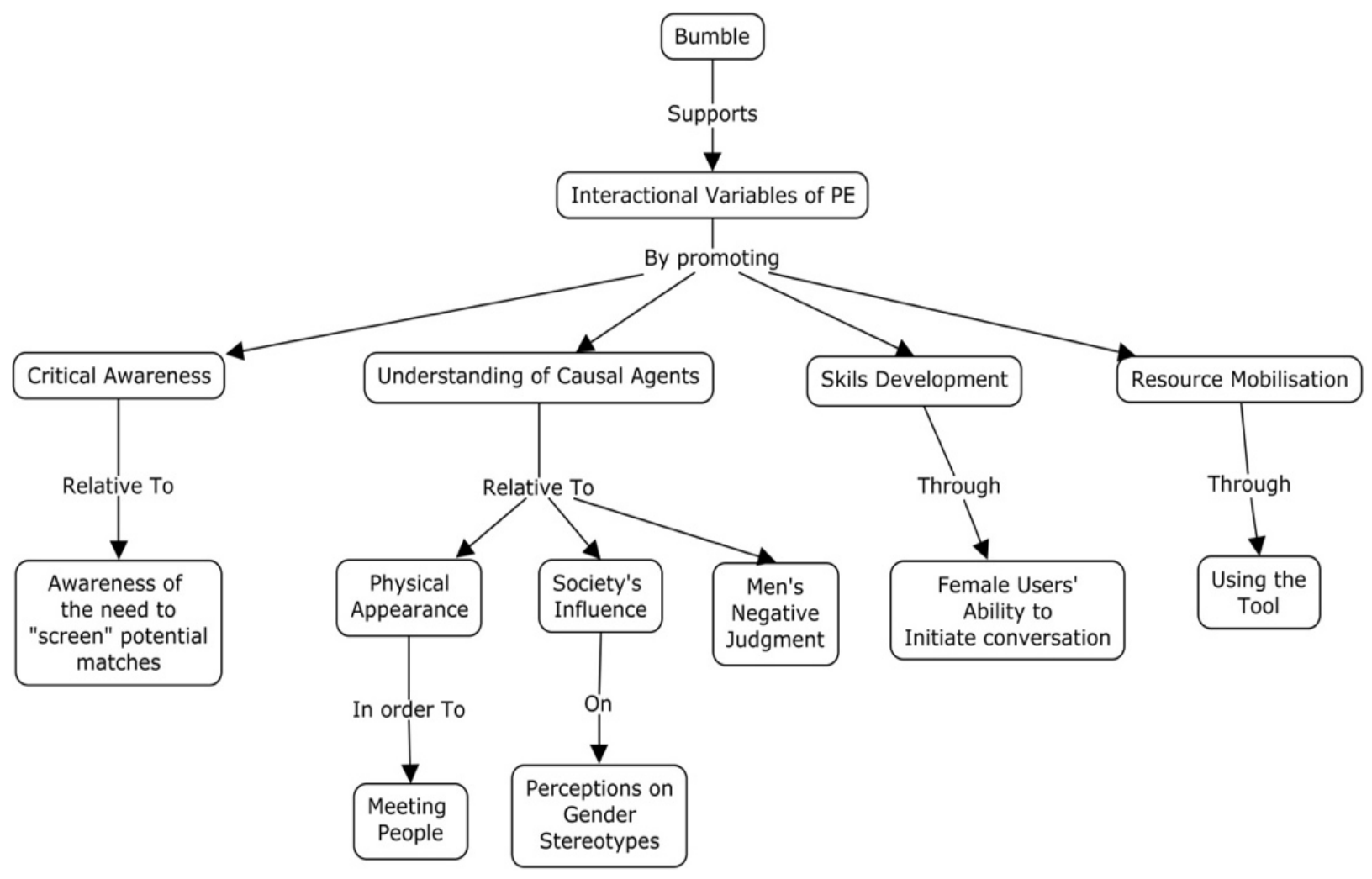

Figure 3. Bumble's supported Interactional Variables of PE

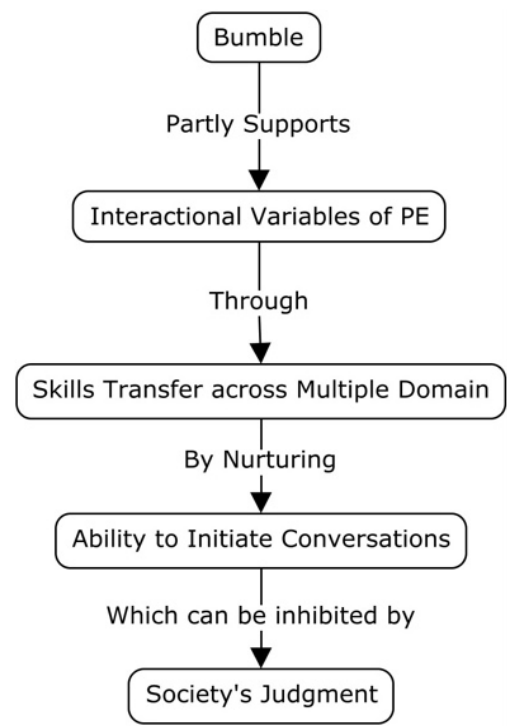

Figure 4. Bumble's partially supported Interactional Variables of PE

\section{THE INFLUENCE OF BUMBLE ON}

\section{BEHAVIOURAL VARIABLES OF PSYCHOLOGICAL EMPOWERMENT}

The behavioral component of PE describes actions that are taken to influence outcomes (Zimmerman, 1995). In the context of the study, only community involvement and coping behaviors were found relevant. Participants did not comment on organizational participation, mostly because it is not directly related to dating or friendship seeking. 
A summary of the findings relative to Bumble and Interactional Variables of psychological empowerment is shown in Figures 3 and 4. From an Informing Science perspective, the study found that in some respects Bumble allows female users to be better informed and thus better understand their world in relation to dating and friendship seeking. For example, in order to achieve critical awareness, Bumble provides some information to users allowing them to screen potential matches. But this is limited to what information is being provided by the informer (i.e., the potential match). The truthfulness and accuracy of the information cannot be $100 \%$ guaranteed by Bumble. Moreover, while the application might seek to promote empowerment by providing women with relevant information through its feature-set, the extent to which this is achieved is still mitigated by external social issues like society's influence and men's negative judgment.

\section{Community involvement}

Community Involvement relates to a person's involvement and participation in community-action activities (Christens et al., 2011). According to the respondents, the only way in which Bumble supported community involvement was through the ability to initiate conversations with their respective matches. Beyond that, the tool did not allow female users to take all the relevant actions fully to achieve their goal. This is further discussed below.

Initiating conversations with matches. Some participants reported that they now have the tendency to initiate random conversations with strangers. The tool allows female users to send messages to potential partners without second thoughts about implications or consequences. As one of the participants puts it: "if I feel like sending a comment because of their profile or like a compliment or whatever, just send it not like think ahead and move on" (Participant A). It's almost as if the implications which would be inherent to such behaviors offline, are eliminated online.

Difficult to filter and identify the right person. In order to fulfill the behavioral component of community involvement, Bumble should promote the ability for female users to take actions to meet suitable and relevant matches and not any random one. Initiating conversation is one thing, but female users stated that they derive a stronger feeling of empowerment when they are able actually to converse with relevant people. Otherwise, it leads to frustration. - it's also very frustrating, and I also don't know if the entertainment is worth the while [...] because of the distance thing but nobody responding thing" (Participant A).

However, the participants explained that the application did not provide all the features to enable this. Female users reported that they were unable to apply filters to restrict potential matches in line with their requirements. Filters could not be applied according to gender, physical distance etc. As a result, they found it difficult to differentiate between genuine and relevant matches and those who were not.

I don't want to be bumping into people I'm not interested in. Yeah so I think that if I could filter my preferences if I'm looking for a certain age group, I can just go for that instead of bumping into people I'm not interested in. (Participant B)

They had to look through people's profile and start interacting with them only to discover that their profile was interesting but the actual person is not. You get to talk to the person, you see that the person is actually not what they said they are (Participant C).

For a pansexual respondent, this was a particularly difficult issue because she mostly obtained male matches, who often had annoying behaviors, leading to her being frustrated.

I think. furthermore with women it's also very difficult, there's not many matches for a woman and other gender. And yeah I found that quite frustrating that most of the matches were just men who were being annoying. (Participant G)

Inability to specify the maximum distance. Bumble does not seem always to display potential matches who are within a specified radius (distance) of the user. This is mostly due to the fact that 
participants could not find any Bumble feature allowing them to specify the maximum distance between them and their potential matches.

For instance, I got people from Johannesburg and people who live in Durban. I think the purpose of having such an app is meeting people in your town or city or whatever and like yeah, I thought that wasn't nice. (Participant D)

Female users' preferences ignored. At times, some female users who specifically wanted to be matched with women were nonetheless being presented with male potential matches. The inability for Bumble always to support gender preferences of users does not contribute to the domainspecific control of female users.

Another challenge, if you just set it up to 'looking for a woman' and sometimes it still pops up with men. (Participant A)

One participant expressed an interesting idea relative to a feature which she would like the Bumble app to have but which it does not currently have. In particular, she felt that the app should learn about her "matching preferences" by keeping track of the type of people that she usually selects (swipe left for). The app should then only suggest matches that align with this profile. In essence, she wanted an app with machine learning enabled features.

I feel like, like my pool is not really, like the people they give me, they don't really base that on the people I've swiped left already. Like in the sense of, like if I swipe left, say for instance Asian guys, then you should kind of, the app should kind of almost click that I'm not into Asian guys right and like obviously not give me that option. So it would be nice to have like, you know the kind of guess that okay I'm not into Asian guys or colored guys or these type of guys, so don't give me that, you know. (Participant E)

Safety issues. Bumble might be a platform which allows female users to meet new people and interact with them, but the safety issue nonetheless still exists, and some participants were aware of it. The app cannot mitigate the risk that female users might incur while choosing to meet face to face with a person that they encountered online. Due to this, some participants had not taken their interactions with their matches to the next level, (i.e., meeting face to face).

I haven't met anyone yet because like I'm skeptical about the safety concerns, but like I've been chatting to like a couple of people or so that's looking good. (Participant B)

According to Hallam et al. (2018), trust issues towards meeting individuals emanate from the risks of meeting potentially harmful or deceptive people, as illustrated in the above quote. This is mostly due to the inherent difficulty in confirming the true identity of the person with whom one is communicating online.

Users credibility cannot be ascertained. Some female users have reported negative experiences with people who had lied about their profile on Bumble. This is an issue that the Bumble app does not seem to be able to control, in spite of allowing for cross-reference through other social media platforms (e.g., Facebook and Instagram). Female users deal with that by blocking these people.

I don't know. People lie. They lie to get attraction, to get - I don't know why people do it, but most of them did it. The ones I've interacted with - they lie about their profile, say something they're not, put pictures - I don't know. Some pictures I think were Photoshopped. (Participant C)

As previously stated, Bumble has the potential to act as a tool that promotes empowerment as a process (Stromquist, 2015; Zimmerman, 2000). However, further investigations reveal that the functionalities provided by the tool still need to be improved to achieve this form of empowerment. This is the case for other mobile dating applications that also utilize similar features. For example, other mobile dating applications like Tinder also give the option to women to initiate conversations, but it is not compulsory. As previously stated, this might contribute to the ability of other mobile dating applications somehow to promote community involvement. 
Mobile Dating Applications and Psychological Empowerment

Privacy and safety remain an issue. As stated by past studies, female users deal with safety risks by blocking users (Smith \& Duggan, 2013) and the tool does not allow for misinformation, disinformation, and deception to be easily recognized. The same challenge applies to other mobile dating applications as they all operate similarly. This is in line with Wang and Lu (2007) who stated that in cyberdating, misinformation relative to personal identity, social status, age and looks amongst others, are prevalent. Further studies are needed to ascertain the extent to which safety and privacy issues are prevalent in other mobile dating applications.

Toma (2015) also noted that in the online dating scene, users tend to be deceptive pertaining to their physical attributes, personal interests, and photos. Mobile dating platforms like Bumble could, therefore, be improved to protect the interests of female users and promote empowerment by incorporating ways of minimizing misinformation, disinformation, and deception. The same applies to other mobile dating platforms, which should also include more stringent requirements to ascertain the credibility of their users and take female users' preferences into consideration in their design.

\section{Coping behaviour}

Coping behavior relates to a person's own effort to solve personal and interpersonal problems with the aim of mastering, minimizing, or tolerating stress and conflict (Weiten et al., 2014). Coping behaviors reported in the study relate to un-matching unsuitable matches.

Un-matching unsuitable people. In contrast to the "real life," female participants explained that through Bumble, they were able to un-match and block any person who behaved inappropriately towards them. They explained that this is something that they cannot necessarily do in face-to-face interactions for fear of negative repercussions.

If someone is not acting right, I can literally unmatch them, and that's the beauty about Bumble. If someone is swearing at me and you know it's being disrespectful, I can literally just unmatched them because I think. it's an advantage. Because like when you meet a person like in real life and really like when you meet in person they will see you again at some point they will bump into you, they might harm you. (Participant B)

Comments like "Oh like send me your sexiest picture or just disrespectful things like that. What else... or if they're just weird", cannot be controlled by the Bumble app, which in contrast appear to eliminate inhibitions and allow for such comments to be made. Some participants have reported that "some guys maybe depending on what pictures you have on your profile they might reply with a comment about it, maybe a sexual kind of comment that obviously comes with all dating sites, so that is like one negative I would say" (Participant C).

This leads to frustrations and a feeling of being harassed. In those cases, un-matching and blocking features were particularly relevant.

I think for me particularly as somebody who identifies as pansexual I find that the men on the app are extremely uncouth sometimes they can be extremely sexual in advances... I found some people were just frustrating me and it got to a stage where it was actually causing me, like anger towards people who are completely unacceptable in their behavior over an app. (Participant $G$ )

One participant explained how in her opinion, men using this application found it easier to objectify a woman through the app because they don't face as much negative social impact. So they can say basically what they want without the consequences of somebody retaliating and yeah for me I found that very frustrating (Participant $G$ ).

A summary of the findings relative to Bumble and Behavioural variables of psychological empowerment is shown in Figures 5, 6, and 7. From an informing science perspective, Bumble is not able to disseminate information effectively enough to achieve psychological empowerment. While the female users are not able to access enough information on their potential match's credibility, they are also unable to filter all the information that is being given to them. This is in line with Wang and Lu (2003) who state that in virtual communications, it is up to the discretion of the addressee to be honest and truth-telling. Consequently, the contextual environment in which the tool operates (i.e., feature-set) is not fully optimized to allow the right information to be made available to the female us- 
ers, at the right time, in order to promote psychological empowerment. Further studies are needed to determine the extent to which this applies to other mobile dating applications.

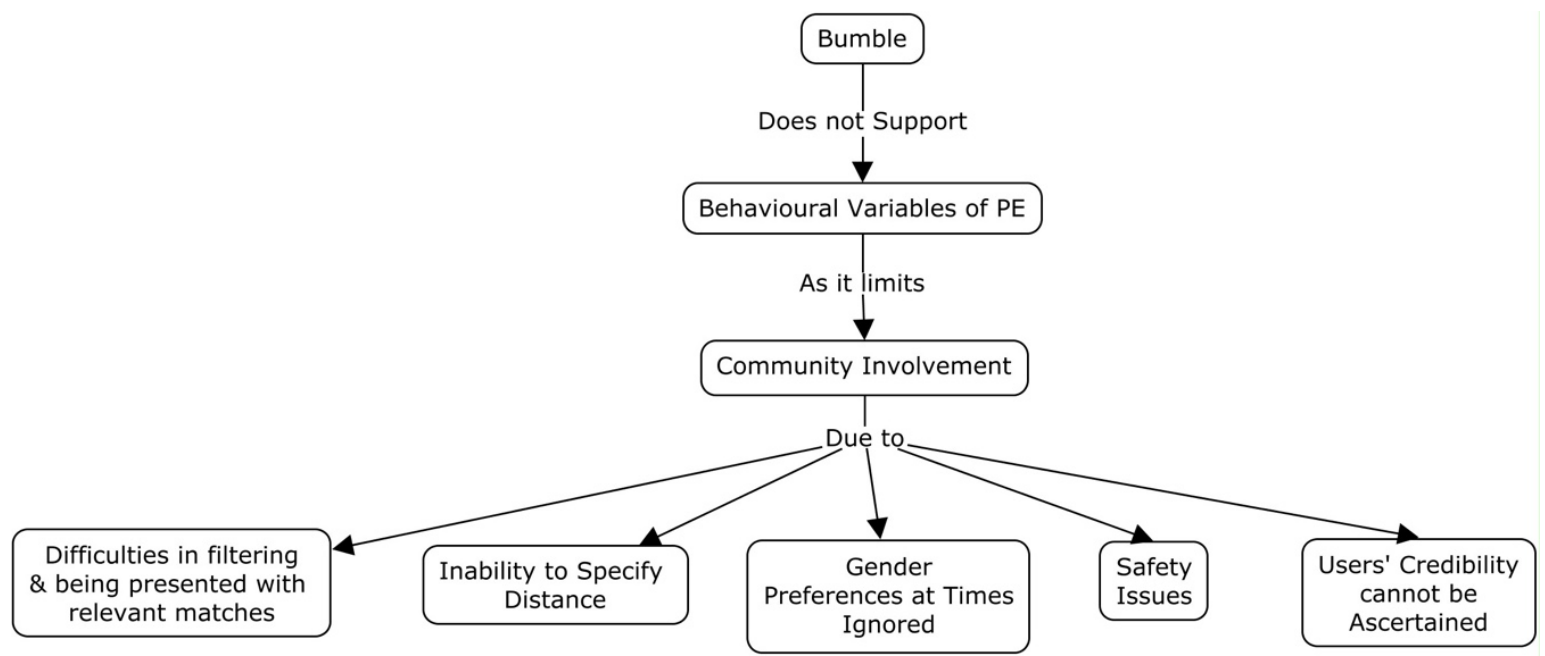

Figure 5. Bumble's unsupported Behavioural Variables of PE

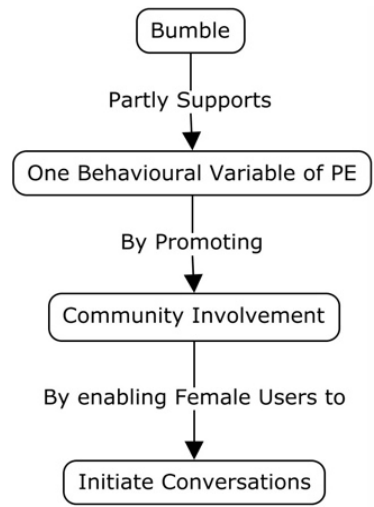

Figure 6. Bumble's partially supported Behavioural Variables of PE

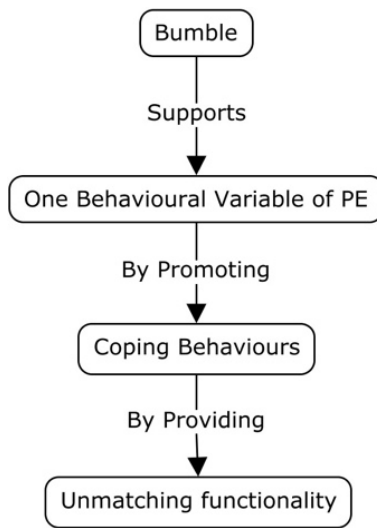

Figure 7. Bumble's supported Behavioural Variables of PE 


\section{CONCLUSIONS}

The purpose of this study was to investigate how Bumble, a counter-heteronormative mobile dating application, creates psychologically empowering conditions for female users who wish to find a romantic partner or friendship. Psychological empowerment was deemed particularly interesting since it has not been studied enough, particularly in relation to women (Francina \& Joseph, 2013). Moreover, since Bumble is reputed for being a mobile dating application that empowers female by allowing them to "make the first move," the study sought to investigate how this so-called empowerment came about for female users.

\section{SUMMARY OF FINDINGS}

It was interesting to note that the availability of information and access to that information through the Bumble app might contribute to women empowerment (i.e. through relevant PE constructs). Bumble allows female users to disseminate information about themselves and to access information about others, as a means to make informed decisions and take actions that could lead to some form of psychological empowerment. However, while Bumble might make relevant information available to the female users, the application does not always provide the right context and feature-set to empower female users fully. The behavioral and social issues prevalent in the contextual environment of the female users and their potential matches still play a role in the extent to which psychological empowerment is achieved. The findings are summarized in Table 6.

\section{Table 6 - Summary of Findings}

\begin{tabular}{|c|c|c|c|}
\hline \multirow{6}{*}{ 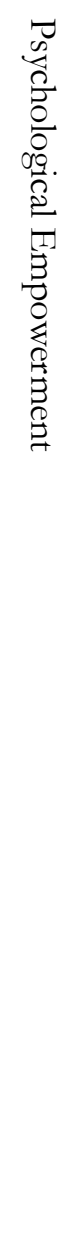 } & \multirow{4}{*}{ 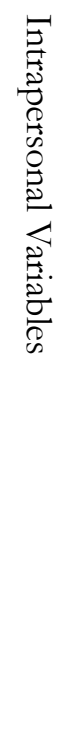 } & $\begin{array}{l}\text { Domain Spe- } \\
\text { cific Perceived } \\
\text { Control }\end{array}$ & $\begin{array}{l}\text { - Female Users feel in control when they are able to swipe to } \\
\text { choose potential partners } \\
\text { - The un-matching functionality allows female users to take control } \\
\text { of how they wish to interact with potential partners }\end{array}$ \\
\hline & & $\begin{array}{l}\text { Domain Spe- } \\
\text { cific Self- } \\
\text { Efficacy }\end{array}$ & $\begin{array}{l}\text { - The ability to initiate conversations on the mobile dating plat- } \\
\text { form, as an expression of self-efficacy, is dependent on the fe- } \\
\text { male user's preferences }\end{array}$ \\
\hline & & $\begin{array}{l}\text { Motivation to } \\
\text { Control }\end{array}$ & $\begin{array}{l}\text { - For female users who wish to take control of their dating life, the } \\
\text { choice of mobile dating platform is dependent on the tools' rep- } \\
\text { utation }\end{array}$ \\
\hline & & $\begin{array}{l}\text { Perceived } \\
\text { Competence }\end{array}$ & $\begin{array}{l}\text { - Female users not receiving enough "matches" can result in feel- } \\
\text { ings of self-doubt } \\
\text { - Female users who receive "matches" may feel a boost of self- } \\
\text { confidence }\end{array}$ \\
\hline & \multirow{2}{*}{ 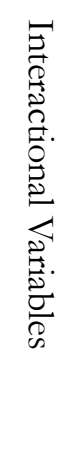 } & $\begin{array}{l}\text { Critical } \\
\text { Awareness }\end{array}$ & $\begin{array}{l}\text { - Female users are aware of the need to screen potential matches } \\
\text { before trusting or being emotionally involved. }\end{array}$ \\
\hline & & $\begin{array}{l}\text { Understanding } \\
\text { of Causal } \\
\text { Agents }\end{array}$ & $\begin{array}{l}\text { - It is important but difficult for female users to detect misinfor- } \\
\text { mation and deception and develop the trust of content while using } \\
\text { mobile dating applications } \\
\text { - Female users of mobile dating applications recognize the need to } \\
\text { "look good" on their profile } \\
\text { - Society's perceptions of gender stereotypes influence how female } \\
\text { users interact with other users }\end{array}$ \\
\hline
\end{tabular}




\begin{tabular}{|c|c|c|}
\hline & & $\begin{array}{l}\text { - Female users are aware of the need to carefully chose the type of } \\
\text { men they initiate conversations with, for fear of negative } \\
\text { judgment }\end{array}$ \\
\hline & $\begin{array}{l}\text { Skill Devel- } \\
\text { opment }\end{array}$ & $\begin{array}{l}\text { - Whilst using a mobile dating application, some female users ac- } \\
\text { quire skills relative to being able to make the first move towards } \\
\text { potential partners }\end{array}$ \\
\hline & $\begin{array}{l}\text { Skill Transfer } \\
\text { across life } \\
\text { domains }\end{array}$ & $\begin{array}{l}\text { - Whilst using a mobile dating application, some female users ac- } \\
\text { quire skills relative to being able to make the first move towards } \\
\text { potential partners offline }\end{array}$ \\
\hline & $\begin{array}{l}\text { Resource Mo- } \\
\text { bilisation }\end{array}$ & $\begin{array}{l}\text { - Female users of mobile dating applications are able to identify } \\
\text { other potential tools which will enable to them to achieve their } \\
\text { goals of forming new relationships }\end{array}$ \\
\hline \multirow[t]{3}{*}{ 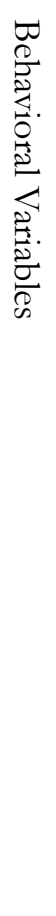 } & $\begin{array}{l}\text { Community } \\
\text { Involvement }\end{array}$ & $\begin{array}{l}\text { - The ability to initiate conversations allow female users to be more } \\
\text { involved in the mobile dating community } \\
\text { - It is difficult for female users to identify and converse with the } \\
\text { right type of person while using mobile dating applications } \\
\text { - Female users are not always able to specify the maximum radius } \\
\text { from which potential matches should be identified. } \\
\text { - The preferences of female users are not always taken into con- } \\
\text { sideration by the mobile dating application when displaying po- } \\
\text { tential matches to them } \\
\text { - Mobile dating applications are not able to mitigate the risks in- } \\
\text { herent in meeting strangers online for female users } \\
\text { - Mobile dating applications do not fully allow female users to } \\
\text { ascertain the credibility of their potential matches }\end{array}$ \\
\hline & $\begin{array}{l}\text { Organisational } \\
\text { Participation }\end{array}$ & No findings relative to organizational participation \\
\hline & $\begin{array}{l}\text { Coping Be- } \\
\text { haviours }\end{array}$ & $\begin{array}{l}\text { - Female users cope with unwanted and inappropriate behaviors } \\
\text { from matches by blocking or un-matching them }\end{array}$ \\
\hline
\end{tabular}

\section{CONTRIBUTIONS OF THE STUDY}

The main contributions of the study relate to knowledge on how key features of mobile dating applications influence various aspects of psychological empowerment for female users. Past studies have highlighted that mobile dating applications and social media influences empowerment, but little was known on how this empowerment came about. Moreover, psychological empowerment, as a multi-variable concept had not been investigated. This study provided more insights into how mobile dating applications influence intrapersonal, interactional and behavioral variables of psychological empowerment. Details of the specific findings relative to each variable are provided in Table 6.

\section{IMPLICATIONS OF THE STUDY}

The findings have implications for both practice and research. From a practice perspective, it appears that the design of mobile dating applications should be enhanced in order to better contribute to the 
psychological empowerment of female users. Aspects that need to be taken into consideration while designing these tools are as follows:

- While the un-matching, blocking, and cross-platform validation functionalities are useful, more features should be included to allow female users to mitigate the risks and uncertainties associated with mobile dating

- Mobile dating applications should include more refined search mechanisms or filters to allow female users to meet more appropriate/relevant matches

- The mobile dating applications should capture more details about the female users' preferences and take those into consideration while searching for potential matches

- Mobile dating applications should include AI functionalities to better track and analyses the swiping patterns of female users and propose potential matches in line with those trends

- Mobile dating applications should have more stringent mechanisms in place to ensure the credibility of the users

- Female users experience inappropriate behaviors from some male users. Mobile dating applications should have more stringent policies and mechanisms in place to handle these types of users.

From a research perspective, further studies are needed to examine how other mobile dating applications are contributing to the psychological empowerment of female users as a means of providing a broader and more accurate understanding of the phenomenon. In addition, many of the issues raised in the paper are not fully under the control of the female users. Features that support psychological empowerment can be updated at any time by the programmers. Moreover, female users cannot always control how other users present themselves (falsified data) or engage with them (inappropriate behaviors). This gives rise to the following question: Are mobile dating applications truly contributing to psychological empowerment or is this empowerment only "perceived" and "is just an illusion." A longitudinal study would be useful to investigate this matter and is recommended.

\section{LIMITATIONS OF THE STUDY}

The main limitation of the study is the fact that the study only focused on the Bumble application and that data was only collected from 10 respondents. However, saturation was reached during data analysis.

Overall, whether the goal is to find a partner, to make friends, or to take control as a female within the dating scene, a mobile dating application alone cannot be the ultimate tool to allow for this to be fulfilled. A mobile dating application is an intermediary or a stepping stone, and more needs to be done relative to changing perceptions. Additional features to better promote psychological empowerment are also needed.

\section{REFERENCES}

Akehurst, J., Koprinska, I., Yacef, K., Pizzato, L., Kay, J., \& Rej, T. (2011, May). Explicit and implicit user preferences in online dating. In Pacific-Asia Conference on Knowledge Discovery and Data Mining (pp. 15-27). Berlin, Heidelberg: Springer. https://doi.org/10.1007/978-3-642-28320-8 2

Albright, J. M., \& Simmens, E. (2013). Flirting, cheating, dating, and mating in a virtual world. In M. Grimshaw (Ed.), The Oxford handbook of virtuality (pp. 284-302). New York, NY: Oxford University Press

Alterovitz, S. S. R., \& Mendelsohn, G. A. (2009). Partner preferences across the life span: Online dating by older adults. Psychology and Aging, 24(2), 513-517. https://doi.org/10.1037/a0015897

Aultman, B. (2014). Cisgender. Transgender Studies Quarterly, 1(1-2), 61-62.

Bandura, A. (1977). Self-efficacy: toward a unifying theory of behavioral change. Psychological Review, 84(2), 191 215. https://doi.org/10.1037/0033-295X.84.2.191 
Baxter, P., \& Jack, S. (2008). Qualitative case study methodology: Study design and implementation for novice researchers. The Qualitative Report, 13(4), 544-559.

Birnholtz, J., Fitzpatrick, C., Handel, M., \& Brubaker, J.R. (2014). Identity, identification and identifiability: The language of self-presentation on a location-based mobile dating app. In Proceedings of the 16th International Conference on Human-Computer Interaction with Mobile Devices \& Services, 3-12. https://doi.org/10.1145/2628363.2628406

Bivens, R., \& Hoque, A. S. (2018). Programming sex, gender, and sexuality: Infrastructural failures in the "Feminist" dating app bumble. Canadian Journal of Communication, 43(3). https://doi.org/10.22230/cjc.2019v44n3a3375

Blackwell, C., Birnholtz, J., \& Abbott, C. (2015). Seeing and being seen: Co-situation and impression formation using Grindr, a location-aware gay dating app. New Media \& Society, 17(7), 1117-1136. https://doi.org/10.1177/1461444814521595

Braun, V., \& Clarke, V. (2006). Using thematic analysis in psychology. Qualitative Research in Psychology, 3(2), $77-$ 101. https://doi.org/10.1191/1478088706qp063oa

Bumble. (n.d.). Frequently asked questions. Retrieved from https://bumble.com/en/faq

Bumble. (2017). We want to make sure every woman knows her options for birth control. Read about an amazing online start up that is taking the hassle out of getting birth control [Facebook post]. Retrieved from https://www.facebook.com/bumbleapp/posts/766429520222877

Burke, K. (2015). How apps like Bumble and Hinge are making dating better for women. Market Watch. Retrieved from https://www.marketwatch.com/story/how-dating-apps-are-getting-better-for-women-2015$\underline{08-12}$

Chan, L. S. (2017). Who uses dating apps? Exploring the relationships among trust, sensation-seeking, smartphone use, and the intent to use dating apps based on the Integrative Model. Computers in Human Behavior, 72, 246-258. https://doi.org/10.1016/i.chb.2017.02.053

Charlot, N. H. (2018). The influence of romantic rejection on change in ideal standards, ideal flexibility, and self-perceived mate $V$ alue (Doctoral dissertation, The University of Western Ontario).

Christens, B. D., Peterson, N. A., \& Speer, P. W. (2011). Community participation and psychological empowerment: Testing reciprocal causality using a cross-lagged panel design and latent constructs. Health Education \& Behavior, 38(4), 339-347. https://doi.org/10.1177/1090198110372880

Clark, L. S. (1998). Dating on the net: Teens and the rise of "pure" relationships. In S. Jones (Ed.), Cybersociety 2.0: Revisiting Computer-Mediated Community and Technology (pp.159-183). Thousand Oaks, CA: SAGE Publications. http://dx.doi.org/10.4135/9781452243689.n6

Cohen, E. B. (2009). A philosophy of informing science. Informing Science: The International Journal of an Emerging Transdiscipline, 12, 1-15. https://doi.org/10.28945/425

Coletta, J. (2018). The missing B word: Compulsory binarization and bisexual representation in children's literature. Jeunesse: Young People, Texts, Cultures, 10(1), 85-108.

Danet, B. (1998). Text as mask: Gender, play, and performance on the internet. In S. Jones (Ed.), Cybersociety 2.0: Revisiting Computer-Mediated Community and Technology (pp. 129-158). Thousand Oaks, CA: SAGE Publications. http://dx.doi.org/10.4135/9781452243689.n5

Dodge, B., Jeffries, W. L., \& Sandfort, T. G. (2008). Beyond the down low: Sexual risk, protection, and disclosure among at-risk Black men who have sex with both men and women (MSMW). Archives of Sexual Behavior, 37(5), 683-696. https://doi.org/10.1007/s10508-008-9356-7

Dubé L., \& Paré G., (2003). Rigor in information systems positivist case research: Current practices, trends, and recommendations. MIS Quarterly, 27(4), 597-636. https://doi.org/10.2307/30036550

Ellison, N., Heino, R., \& Gibbs, J. (2006). Managing impressions online: Self-presentation processes in the online dating environment. Journal of Computer-Mediated Communication, 11(2), 415-441.

https://doi.org/10.1111/j.1083-6101.2006.00020.x 
Mobile Dating Applications and Psychological Empowerment

Emery, L. R. (2017). The most popular dating apps in 2017, because an OG is the clear winner. Retrieved 17 October 2018 from https://www.bustle.com/p/the-most-popular-dating-apps-in-2017-because-og-is-the-clearwinner-38692

Francina, P. X., \& Joseph, M. V. (2013). Women empowerment: The psychological dimension. Rajagiri Journal of Social Development, 5(2), 163-176.

Gibbs, J. L., Ellison, N. B., \& Heino, R. D. (2006). Self-presentation in online personals: The role of anticipated future interaction, self-disclosure, and perceived success in Internet dating. Communication Research, 33(2), 152-177

Gibbs, J. L., Ellison, N. B., \& Lai, C.-H. (2011). First comes love, then comes Google: An investigation of uncertainty reduction strategies and self-disclosure in online dating. Communication Research, 38(1), 70-100. https://doi.org/10.1177/0093650210377091

Gibson, J. J. (1979). The theory of affordances. In J. J. Gibson, The ecological approach to visual perception (pp. $127-$ 143). Houghton Mifflin.

Gonel, A. H. (2013). Pansexual identification in online communities: Employing a collaborative queer method to study pansexuality. Graduate Journal of Social Science, 10(1), 36-59.

Guadagno, R. E., Okdie, B. M., \& Kruse, S. A., (2012). Dating deception: Gender, online dating, and exaggerated self-presentation. Computers in Human Behavior, 28(2), 642-647. https://doi.org/10.1016/i.chb.2011.11.010

Gustafsson, J. (2017). Single case studies vs. multiple case studies: A comparative study, Retrieved from http://www.divaportal.org/smash/get/diva2:1064378/FULLTEXT01.pdf

Hallam, L., Walrave, M., \& De Backer, C. J. (2018). Information disclosure, trust and health risks in online dating. In M Walrave, J. Van Ouytsel, K. Ponnet, \& J. Temple (Eds), Sexting (pp. 19-38). Palgrave Macmillan, Cham. https://doi.org/10.1007/978-3-319-71882-8 2

Hamid, N. A., Ishak, M. S. \& Yusof, N. (2016). Assessing validity and reliability of social media as an empowerment tool for a group at risk in Malaysia. Journal Komunikasi, Malaysian Journal of Communication, 32(1)

Hess, A., \& Flores, C. (2016). Simply more than swiping left: A critical analysis of toxic masculine performances on Tinder Nightmares. New Media \& Society, 1-18.

Hirshman, L. (2012). Victory: The triumphant gay revolution. How a despised minority pushed back, beat death, found love, and changed America for everyone. Harper Collins.

Hobbs, M., Owen, S. \& Gerber, L. (2016). Liquid love? Dating apps, sex, relationships and the digital transformation of intimacy. Journal of Sociology, 53(2), 271-284. https://doi.org/10.1177\%2F1440783316662718

James, J. L. (2015). Mobile dating in the digital age: Computer-mediated communication and relationship building on Tinder (Doctoral dissertation).

Kasturirangan, A. (2008). Empowerment and programs designed to address domestic violence. Violence Against Women, 14(12), 1465-1475. https://doi.org/10.1177/1077801208325188

Kieffer, C. H. (1984). Citizen empowerment: A developmental perspective. Prevention in Human Services, 3(2-3), 9-36. https://doi.org/10.1300/J293v03n02 03

Licoppe, C., Rivière, C. A., \& Morel, J. (2016). Grindr casual hook-ups as interactional achievements. New Media \& Society, 18(11), 2540-2558. https://doi.org/10.1177/1461444815589702

Ling, R., (2004). The mobile connection: The cell phone's impact on society. Morgan Kaufmann.

Lopes, M. R., \& Vogel, C. (2017). Women's perspective on using Tinder: A user study of gender dynamics in a mobile device application. In Proceedings of the 35th ACM International Conference on the Design of Communication, 12. ACM. https://doi.org/10.1145/3121113.3121220

MacLeod, C., \& McArthur, V. (2018). The construction of gender in dating apps: An interface analysis of Tinder and Bumble. Feminist Media Studies, 1-19. https://doi.org/10.1080/14680777.2018.1494618 
Markowitz, D. M., \& Hancock, J. T. (2018). Deception in mobile dating conversations. Journal of Communication, 68(3), 547-569. https://doi.org/10.1093/joc/jqy019

Martin, J. I., \& Yonkin, D. R. (2006). Transgender identity In D. F. Morrow \& L. Messinger (Eds.), Sexual orientation and gender expression in social work practice: Working with gay, lesbian, bisexual, and transgender people (pp. 105128). West Sussex, England: Columbia University Press.

Mason, C. L. (2016). Tinder and humanitarian hook-ups: The erotics of social media racism. Feminist Media Studies, 16(5), 822-837. https://doi.org/10.1080/14680777.2015.1137339

McLeod, S. (2014). Sampling methods. Simply Psychology. Retrieved from https://www.simplypsychology.org/sampling.html

McWilliams, S., \& Barrett, A. E. (2014). Online dating in middle and later life: Gendered expectations and experiences. Journal of Family Issues, 35(3), 411-436. https://doi.org/10.1177/0192513X12468437

Merkle, E. R. \& Richardson, R. A. (2000). Digital dating and virtual relating: Conceptualizing computer mediated romantic relationships. Family Relations, 49(2), 187-192. https://doi.org/10.1111/j.17413729.2000.00187.x

Metzger, M. J., \& Flanagin, A. J. (2013). Credibility and trust of information in online environments: The use of cognitive heuristics. Journal of Pragmatics, 59, 210-220. https://doi.org/10.1016/j.pragma.2013.07.012

Morgan, E. M., Richards, T. C., \& VanNess, E. M. (2010). Comparing narratives of personal and preferred partner characteristics in online dating advertisements. Computers in Human Behavior, 26(5), 883-888. https://doi.org/10.1016/i.chb.2010.02.002

Mosedale, S. (2005). Assessing women's empowerment: Towards a conceptual framework. Journal of International Development, 17(2), 243-257. https://doi.org/10.1002/jid.1212

Nicholls, J. G. (1989). The competitive ethos and democratic education. Harvard University Press.

Paulhus, D., 1983. Sphere-specific measures of perceived control. Journal of Personality and Social Psychology, 44(6), 1253-1265. https://doi.org/10.1037/0022-3514.44.6.1253

Rappaport, J. (1984). Studies in empowerment: Introduction to the issue. Prevention in Human Services, 3(2-3), 1-7

Ranzini, G., \& Lutz, C. (2017). Love at first swipe? Explaining Tinder self-presentation and motives. Mobile Media \& Communication, 5(1), 80-101. https://doi.org/10.1177/2050157916664559

Rocha Santos, P. C. (2018). Gamification of love: A case study of Tinder in Oslo (Master's thesis).

Saunders, M., Lewis, P., \& Thornhill, A. (2012). Research methods for business students. Edinburgh Gate: Pearson Education Limited

Scharlott, B.W. \& Christ, W.G. (1995). Overcoming relationship-initiation barriers: The impact of a computerdating system on sex role, shyness, and appearance inhibitions. Computers in Human Behavior, 11(2), 191-204. https://doi.org/10.1016/0747-5632(94)00028-G

Servaes, J. \& Hoyng, R. (2017). The tools of social change: A critique of techno-centric development and activism. New Media \& Society, 19(2), 255-271. https://doi.org/10.1177/1461444815604419

Smith, A. W., \& Duggan, M. (2013). Online dating \& relationship. Washington, DC: Pew Research Center.

Sprecher, S. (2009). Relationship initiation and formation on the Internet. Marriage \& Family Review, 45(6-8), 761-782. https://doi.org/10.1080/01494920903224350

Spreitzer, G. M., Kizilos, M. A., \& Nason, S. W. (1997). A dimensional analysis of the relationship between psychological empowerment and effectiveness satisfaction, and strain. Journal of Management, 23(5), 679-704.

Stavrositu, C. \& Sundar, S. S. (2012). Does blogging empower women? Exploring the role of agency and community. Journal of Computer-Mediated Communication, 17(4), 369-386. https://doi.org/10.1111/j.10836101.2012.01587.x

Stromquist, N. P. (2015). Women's empowerment and education: Linking knowledge to transformative action. European Journal of Education, 50(3), 307-324. https://doi.org/10.1111/ejed.12137 
Mobile Dating Applications and Psychological Empowerment

Sue, S. \& Zane, N. (1980). Learned helplessness theory and community psychology. In M. S. Gibbs \& J. R. Lachenmeyer (Eds.), Community psychology: Theoretical and empirical approaches, 121-143.

Tahir, M. A. \& Rana, S. A. (2013). Balochistan: An evaluation of the level of psychological empowerment and well-being among Baloch and other ethnic Groups. The Dialogue, 8(1), 85-97.

Tang, D. T. S. (2017). All I get is an emoji: Dating on lesbian mobile phone app Butterfly. Media, Culture \& Society, 39(6), 816-832. https://doi.org/10.1177/0163443717693680

Tepper, F. (2016). Bumble is finally monetizing with paid features to better help you find a match. Tech Crunch. Retrieved from https://techcrunch.com/2016/08/15/bumble-is-finally-monetizing-with-paid-features-tobetter-help-you-find-a-match/

Toma, C. L. (2015). Online dating. In C. Berger, \& M. Roloff (Eds.), The international encyclopedia of interpersonal communication (pp. 1-5). Hoboken, NJ: John Wiley \& Sons, Inc. https://doi.org/10.1002/9781118540190.wbeic118

Toma, C. L. \& Hancock, J. T. (2010). Looks and lies: The role of physical attractiveness in online dating selfpresentation and deception. Communication Research, 37(3), 335-351. https://doi.org/10.1177/0093650209356437

Toma, C. L., Hancock, J. T. \& Ellison, N. B. (2008). Separating fact from fiction: An examination of deceptive self-presentation in online dating profiles. Personality and Social Psychology Bulletin, 34(8), 1023-1036. https://doi.org/10.1177/0146167208318067

UN Women. (2017). Annual Report 2016-2017. Retrieved from http://www2.unwomen.org/$\angle$ media/annual $\% 20$ report/attachments/sections/library/un-women-annual-report-2016-2017en.pdf?vs $=5634$

Unwin, T. (2009). The technologies: Identifying appropriate solutions for development needs. In T. Unwin, ICT4D: Information and Communication Technology for Development (pp. 76-119). Cambridge University Press.

Wang, H., \& Lu, X-A. (2003). Panel on maintaining identity in the virtual world: Fraud and misinformation in the New Age. In Proceedings of Informing Science \& IT Education Conference (InSITE), 1545-1551. https://doi.org/10.28945/2731

Wang, H., \& Lu, X-A. (2007). Cyberdating: Misinformation and (dis)trust in online interaction. Informing Science: The International Journal of an Emerging Transdiscipline, 10, 1-15. https://doi.org/10.28945/453

Ward, J. (2017). What are you doing on Tinder? Impression management on a matchmaking mobile app. Information, Communication \& Society, 20(11), 1644-1659. https://doi.org/10.1080/1369118X.2016.1252412

Weiten, W., Dunn, D. S., \& Hammer, E. Y. (2014). Psychology applied to modern life: Adjustment in the 21st century. Cengage Learning

Yin, R. K. (2013). Case study research: Design and methods. Sage Publications

Zimmerman, M. A. (1995). Psychological empowerment: Issues and illustrations. American Journal of Community Psychology, 23(5), 581-599. https://doi.org/10.1007/BF02506983

Zimmerman, M. A. (2000). Empowerment theory: Psychological, organizational and community levels of analysis. In J. Rappaport \& E. Seidman (Eds.), Handbook of community psychology (pp. 43-63). New York, New York: Kluwer Academic / Plenum Publishers

Zimmerman, M. A. \& Rappaport, J. (1988). Citizen participation, perceived control, and psychological empowerment. American Journal of Community Psychology, 16(5), 725-750. https://doi.org/10.1007/BF00930023 


\section{BIOGRAPHIES}

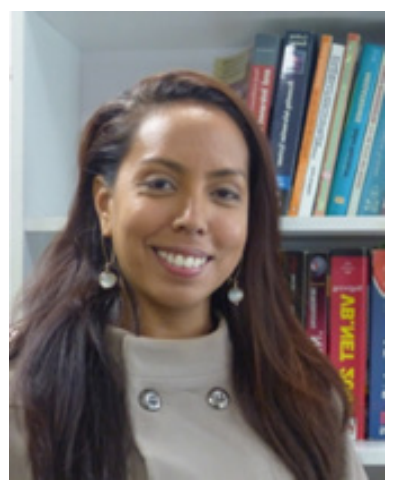

A/Prof Maureen Tanner has been teaching systems analysis and design at the Department of Information Systems of the University of Cape Town since 2009. Her research interests lie in Social Media, Agile software development related issues (for both collocated and distributed teams), UML, software engineering and social aspects of social engineering, global software development, virtual teams, and team collaboration.

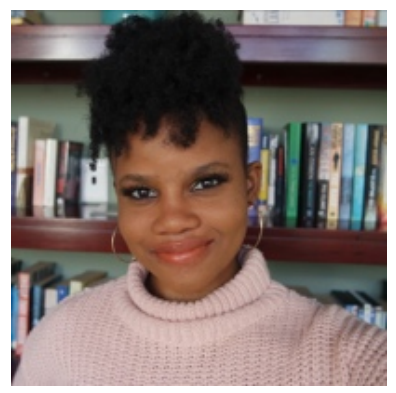

Pabie Tabo is an aspiring world-changer with a strong interest in the field of ICT4D. She has confidence in ICT's potential in helping societies realise equality, equity, and freedom. 